\title{
The Effect of NADES Ratio Solvent and Sonication Time in Extraction of Papaya Sap for Bio-insecticide Production
}

\author{
M F Zikri ${ }^{1}$, A Tibrizi ${ }^{1}$, Y Marsino $^{1}$, T S Utami ${ }^{1}$, R Arbianti $^{1}$, H Hermansyah $^{1}$ \\ ${ }^{I}$ Department of Chemical Engineering, Faculty of Engineering Universitas Indonesia, Depok 16424, Indonesia. Tel. +62 \\ 21 7863516, Fax.+62 21 7863515; E-mail:nana@che.ui.ac.id
}

\begin{abstract}
Along with the increasing quantity of agriculture in Indonesia, should be followed by improving the quality of agriculture. Generally one of the indicators or parameters commonly used to indicate the quality of agriculture is the number of pests that damage plants in certain areas. The control of disturbing organisms on the plant can be minimized by the bio-insecticide production of Carica papaya which is tapped and extracted with ultrasonic-assisted using a mixed NADES solvent from Cholin chloride $(\mathrm{ChCl})$ and Oxalic acid $(\mathrm{Ox})$ with varying sonification time for 10, 20, 30 minutes and solvent ratio of 1: 2 and 2: 1. Bio-insecticide was produced by conducting qualitative enzyme activity of with lowry method and quantitatively using UV / Vis spectrophotometer aid with $750 \mathrm{~nm}$ wavelength and efficacy test. The best extraction result was obtained at NADES solvent with 1: 2 ratio with extraction time for 30 min with extraction time for 30 minutes yielding protein concentration equal to $7,23 \mathrm{ppm}$ and tyrosine concentration equal to 7,9 ppm. Bio-insecticide samples effectively kill grayak caterpillars with $100 \%$ mortality within $5-7$ days.
\end{abstract}

\section{Introduction}

Indonesia is an area with abundant natural resources, making Indonesia known as an agrarian country. The fact is that most of the livelihoods of the Indonesian population come from the agricultural sector and make the agricultural sector one of the great pillars of the Indonesian economy, which is why our country is called an agrarian country. Because it has a very potential area to develop businesses in the agricultural sector.

Some examples of natural resources from the agricultural sector are like soybeans, taro, broccoli and others. This natural resource is widely used for consumption of raw materials for food and feed industry. Its needs also increase from year to year as the food and feed industry grows. In an effort to increase the production of natural resources also need to consider how optimal production is produced from agricultural land that is protected from pests.

One of the pests that attack the agricultural sector is grayak caterpillar pests (Spodoptera sp.). Butterfly pest spreaders easily lay eggs on the leaves of plants and grow. So along with the opening of new farms the need for pesticides also increased. Whereas using chemical pesticides can cause pests to become resistant to pesticides, accumulation of chemicals on agricultural products, environmental damage and soil fertility is reduced.

These negative impacts can be avoided by using bioinsecticides that work by infecting pests so that the pests are no longer able to damage the plant. Bio-insecticides have the same effectiveness as chemical-based pesticides. Another advantage of bio-insecticides is environmentally friendly, leaving no residues that harm plants and the environment can also be produced from natural materials that are abundant in Indonesia. One of the natural ingredients that can be used to produce bioinsecticide is sap papaya (Carica papaya).

Carica papaya is rich in four endopeptidase cysteine such as papain, kimopapain, gisil endopeptidase and caricain [7]. When the papaya plant is injured, the sap will come out and the enzymes will become active. The amount of papain is relatively small, but it is more studied because it is more easily purified. In addition papain is a contact poison where pests will die when contact directly with papain compounds in the papaya plant. Because papain can enter the body of pests through the natural holes of the pest body that can break down proteins, lipids and chitin contained in the body of the pest. Therefore, protease cysteine enzymes have the potential to be developed as bio-insecticide active ingredients. The bio-insecticide production was first Carica papaya tapped and then extracted with ultrasonic waves using NADES solvent. The NADES solvent used was a mixture of $\mathrm{ChCl}$ and oxalic acid with variations in the ratios of 0.5 and 2 moles and the time of sonication for 10, 20 and $30 \mathrm{~min}$ and also ethanol as a comparison. Bio-insecticides are produced by performing quantitative tests of proteins by lowry and efficacy test.

\footnotetext{
Corresponding author: nana@che.ui.ac.id
} 


\section{Methods}

After the research scheme is prepared and planned, the implementation of the research will be carried out in certain procedures. This study consisted of 3 stages, namely the extraction of protease cysteine enzyme from sap, papaya enzyme activity test and efficacy test.

The extract results obtained are still in the form of crude so that it will be given folin and biuret reagents for later measured absorbance to be plotted into the standard curve for known enzyme concentration contained in the extract. Then test the enzyme activity by calculating the tyrosine concentration formed based on the measured absorbance value of the sample that has been given the folin reagent. The last test is a measurement of the effectiveness of bio-insecticides made, ie by testing efficacy. This test was performed by giving bioinsecticides to the corn leaves, which were then given to the grayak worms tested. The data taken in the percentage of the caterpillar is dead and the percentage of leaves are inedible.

The variables varied in this study were, the ratio of NADES solvent used and also the time of sonication.

\subsection{Ultrasonic-Assisted Extraction (UAE)}

Ultrasound-Assisted Solvent Extraction (UAE) is a maceration method (incorporating plant powders and suitable solvents into a closed inert container) modified using ultrasound aid (high frequency signal, $20 \mathrm{kHz}$ ). Containers containing sample powders are placed in ultrasonic and ultrasound containers. This is done to provide mechanical pressure on the cell to produce a cavity in the sample. Cell damage can cause increased solubility of the compound in the solvent and increase the extraction rate [5].

This ultrasonic wave technique or method is also known as sonokimia that utilizes the effects of ultrasonic waves to influence the changes that occur in chemical processes. The main advantages of ultrasonic wave extraction include greater efficiency, shorter operating times, and usually faster displacement rates when compared with conventional extraction in general, eg by the soxhlet method (placing the sample powder in a cellulose holster in a clutch placed above the flask and under condenser) [2].

Things that affect the ability of ultrasound to cause cavitation effects applied to food products include ultrasonic characteristics such as frequency, intensity, amplitude, power, product characteristics (such as viscosity and surface tension) and surrounding conditions such as temperature and pressure [9].

\subsection{Analysis}

Here are the equations used for data processing for the determination of protease cysteine enzyme activity present in biopesticide produced from papaya sap as well as percentage mortality of grayak caterpillar (Spodoptera sp.).

\subsubsection{Calculation of Cystein Protease Enzyme Activity}

The analysis to find out the most effective extracting method for taking proteist cysteine enzyme from papaya sap is by measuring the amount of enzyme activity produced. Because a method is said to be effective when the enzyme activity produced great does not decrease too significantly after being stored for a period of time and at a certain temperature. The way of measuring the amount of enzyme activity produced is:

\section{(Sample Absorbance/Standard Absorbance) x Standard Concentration

While to know the absorbance of standard and standard concentration first made calibration curve. The solution used as a standard solution is a tyrosine solution that has been varied in concentration.

\subsubsection{Calculation of Mortality Rate of Grayak Larvae}

The analysis to find out the most effective extracting method to take the enzyme cysteine protease and papaya plant part that produce papaya sap with more protease cysteine enzyme content is by performing efficacy test that is by giving the leaves that have been given biopesticide solution on grayak caterpillar in the cup petri and observed for 7 days. The higher mortality rate of grayak caterpillar larvae and the less percentage of leaves eaten by caterpillar grayak shows that cysteinebased biopesticide protease from papaya sap is effective in pest- fighting. The equation used to determine mortality rate of grayak larvae is as follows:

$$
(M)=(d-N) \times 100 \%
$$

With $\mathrm{d}$ is the number of dead pests; $\mathrm{N}$ is the number of pests tested; and M mortality (\%).

\section{Result and Discussion}

In this chapter will be discussed about the results of research that has been done. The discussion includes the amount of protein concentration, the amount of cysteine protease enzyme with the activity of papain enzyme extract for variation of the solvent ratio and the extraction time of the extract produced. As well as mortality in caterpillars on effectiveness testing or efficacy testing. In the test plus samples from ethanol as a comparison of the results of the NADES (ChCl- Ox) solvent used.

After obtaining the extraction result using a sonicator with variation of time and solvent ratio, protein concentration testing was done. This test is performed to find out how much protein content in the form of papain enzyme in the sample of the extraction results. The measurement of this protein concentration using the Lowry method. The extract sample is reacted with the biuret and the Folin-Ciocalteu reagent 
will produce a blue color, the thicker the color the greater the concentration of the protein contained therein. The results of this color serve as an indicator of protein content in samples of a qualitative nature.

While that is quantitative done with the help of UV / Vis spectrophotometer. To see how much the concentration of the contained protein was measured at a wavelength of $750 \mathrm{~nm}$ and calculated using absorbance values calculated using standard curves with measurable BSA (Bovin Serum Albumin) concentrations. Here is a graph of protein concentration test results from extract samples with time variation and also solvent ratio of NADES and ethanol:

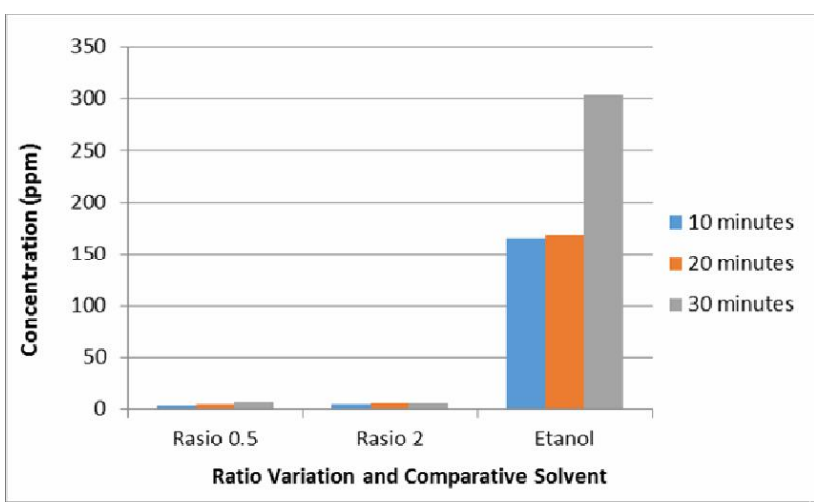

Fig 1. Protein Concentrations Result

Based on the above graph it can be seen that the concentration of proteins from the extract showed ethanol as a comparative solvent having the highest protein content in a 10 minute extraction time variation of 165.56 ppm, 20 minutes at 169.16 ppm and 30 minutes at 304.12 ppm. While on the NADES solvent tested that had a protein content at a ratio of $1: 2$ or 0.5 of $4.50 \mathrm{ppm}$ for a time variation of 10 minutes, $5.35 \mathrm{ppm}$ for a time variation of 20 minutes and $7.23 \mathrm{ppm}$ for time variation 30 minutes. Compared with a ratio of 2: 1 or 2 which has a protein concentration at 10,20 and 30 minutes time variations of $5.24,5,78,6.11 \mathrm{ppm}$. The acquisition of this protein concentration when viewed qualitatively as to why ethanol is higher than that of NADES solvent used is when the yield of the extract using ethanol is reacted with the biuret and the Folin- Ciocalteu reagent produces a less intense blue color which means it has a fairly high protein content. While the result of extraction using NADES solvent is not blue color but greenish yellow color indicating that protein content of the extract is not so much, it can be seen quantitatively using UV / Vis spectrophotometer with result like graph above. Based on the literature [1] extraction using NADES solvent (ChClLa) with a ratio of $1: 2$ or 0.5 indicates a high extraction ability, whereas in studies performed on a 2: 1 or 2 ratio that has extraction capability using NADES solvent $(\mathrm{ChCl}-\mathrm{Ox})$ is better. Thus the protein concentration in the extract produced with the NADES solvent is at a 2: 1 or 2 ratio. However, when the sonication is performed to extract from a sample using NADES solvent with 2 ratios of 1: 2 or 0.5 and 2: 1 or 2 ratios and ethanol as the comparative solvent, all show concentration increases from the 10th minute to the 30th minute. Based on the literature the increase in concentration shows that the extraction efficiency increases with time. The 10 to 30 period is the best time to break the cell wall. Extraction using a prolonged sonicator over 30 minutes did not result in a significant increase, which means the optimum time for extraction was 30 minutes [10].

The inequality of acquiring protein concentration from the extraction may be due to the tapping method. The removal of papaya sap from the skin of the fruit is susceptible to contamination with fluid contained in the fruit. The fruit peels are scratched with a knife with a thickness of 2-3 $\mathrm{mm}$, but the knife blade is different, allowing a thickness of more than $3 \mathrm{~mm}$ to cause fluid in the fruit to flow. Therefore, the sap becomes more fluid and due to the mixing of the sap and fluid of the fruit to make the protein concentration becomes reduced.

After testing protein concentrations, the study continued with enzymatic activity test. This test is also the same as the previous test that is by using the Lowry method but the use of different standards. If testing of protein concentrations using BSA (Bovin Serum Albumin), then on testing this enzymatic activity using Ltyrosine as a measured standard. The data obtained on this test also used the UV / Vis spectrophotometer to see how much of the enzymatic activity in the extraction using NADES solvent with a ratio of 1: 2 and 2: 1 ratio, as well as the variation of extraction time within $10,20,30$ minutes and ethanol as a comparative solvent measured with a wavelength of $750 \mathrm{~nm}$. To obtain the relationship of enzymatic activity with the concentration of tyrosine, the following equation is used:

$$
V=-(d[S] / d t)=d[P] / d t
$$

With $\mathrm{V}$ is conversion rate; $[\mathrm{S}]$ is substrate concentration; $[\mathrm{P}]$ is product concentration; and $\mathrm{t}$ is reaction time.

The enzymatic activity is directly proportional to the concentration of the product, so that the sample with the product concentration of the most tyrosine will be determined as the sample with the highest enzymatic activity. In the research, the concentration of the highest enzymatic activity test was extracted using NADES solvent with 1: 2 ratio in extraction time for 30 minutes.

The operating temperature conditions also affect the enzymatic activity. Temperatures can make the molecules move more randomly and rapidly, increasing the frequency of collisions between enzyme molecules and substrate [4]. To that end, each sample was incubated at the optimum temperature of protease ie 370C [11].

According to [3] the substance of papain contained in papaya sap is a substance that is easily contaminated and oxidized. While the tapping process is under conditions under the sun and open air conditions so that the papaya gum will freeze and clot then papain will become oxidized. Papain itself is a class of protease cysteine enzymes in which there is sulfihydryl on the active site. The active side of the papain can be inactive by the oxidation process. While ultraviolet rays from sunlight precisely accelerate the run of oxidation reactions [3]. As for this research, the tapping is done at $9 \mathrm{am}$, although the sunlight has not been as bright as at 12 noon, but the 
sunlight at that time is enough to make the quality of papain tapping down so that the value of activity unit also decreased. Here are the results of measurements of the test of enzymatic activity in graphical form:

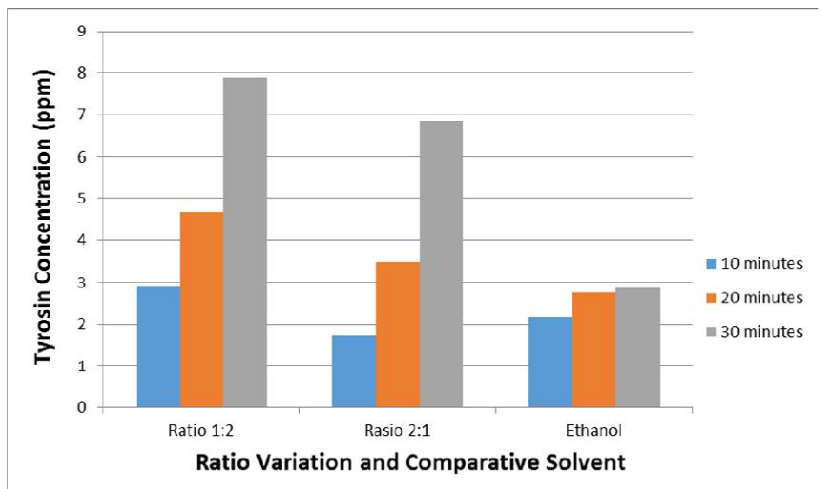

Fig 2. Enzymatic Activity Result

Based on the above graph it can be seen that the enzymatic activity on the extraction results using NADES solvent with variation of ratio and time and ethanol as different comparative solvents. Seen at the time of sonication for extracting a sample using NADES solvent with 2 ratios of 1: 2 and 2: 1 ratios and ethanol as a comparative solvent, as well as testing of protein concentrations, all of which also showed increased concentrations of minute to 10 to 30 minutes which means the optimum time to extraction is 30 minutes [10].

To determine the mortality of caterpillar performed efficacy testing. Tests of efficacy were performed to determine the effectiveness of bio-insecticides made against grayak caterpillar to be eradicated. In this efficacy test the contact between the bio-insecticide sample and the grayak caterpillar is stomach contact. Sample of bioinsecticide will be applied to broccoli leaves which will be used as food on grayak caterpillar. Grayak caterpillars that are tested are caterpillars that are in instar phase 3 . This is because at the instar phase 3 caterpillar is actively eating. So it is expected that biopesticide samples are made to reduce the activity of caterpillar feeding and even can kill the caterpillar. Based on the research, the observation on the percentage mortality of caterpillar grayak can be seen in the following tables and graphs:

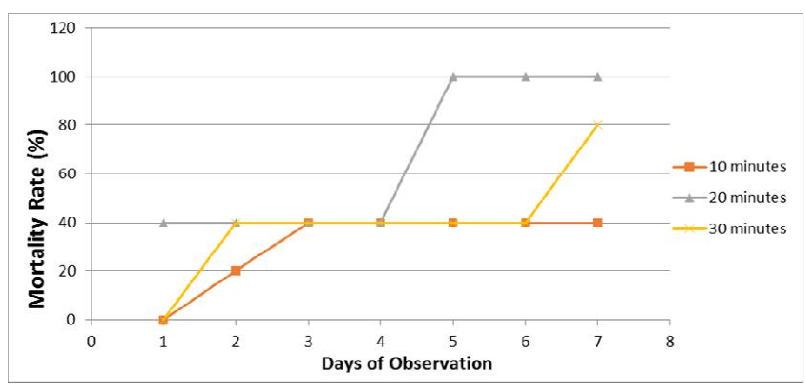

Fig 3. Mortality Rate of Ratio $1: 2$

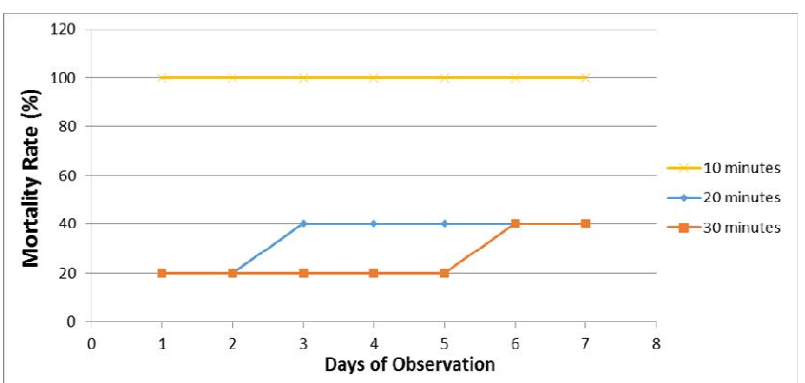

Fig 4. Mortality Rate of Ratio $2: 1$

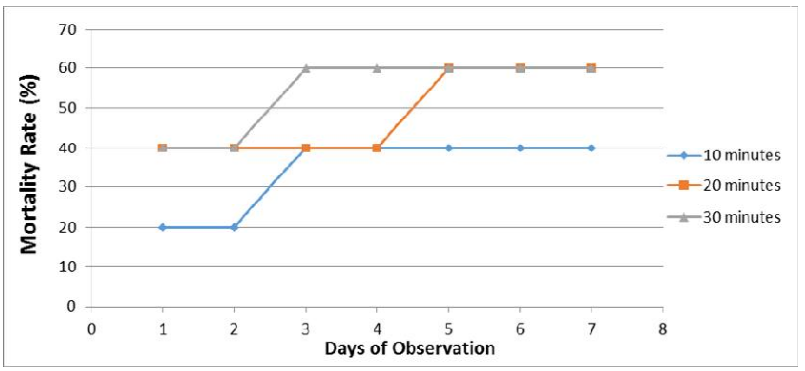

Fig 4. Mortality Rate of Ethanol

Based on the graph it can be seen that the bioinsecticide sample proved to be effective in stopping the grayak caterpillar for the NADES solvent ratio at a particular time variation. Percentage of caterpillar mortality reached $100 \%$ at $1: 2$ ratio in extraction time for $20 \mathrm{~min}$, and at 2: 1 ratio in extraction time for 10 min. While ethanol only has a $40 \%$ mortality rate at the time of extraction 10 minutes, $60 \%$ at 20 and 30 minutes. In the graph can also be seen that the most rapid sample reaching $100 \%$ percentage mortality is the sample extracted using NADES solvent with a 2: 1 ratio in extraction time for 10 minutes. This suggests that a sample of bio-insecticides containing a cysteine protease enzyme in papain form can kill a grayak caterpillar.

Due to the content of enzyme papain which is a class of enzyme cysteine protease works actively as toxin that enter into body and can decrease grayak caterpillar activity. The working system of papain enzyme as a stomach poison in the body of the grayak caterpillar will be absorbed by the existing wall of the digestive organ of the grayak caterpillar, then sent to the nerve center thus potentially putting pressure on and reducing the internal organ metabolism which leads to mortality [6].

Aside from being a stomach poison, the contact between leaves exposed to bio-insecticidal samples with caterpillar skin during the testing process in petri dishes can also interfere with the process of skin turnover in caterpillars. Papain compounds are contact poisons that enter the caterpillars through natural holes from the caterpillar body that can break down proteins, lipids and chitin contained in the caterpillar body. So with the destruction of the protein in the body of the caterpillar, the caterpillar will experience obstacles in the development of its integument where the process of skin changes will not be perfect [8] so the caterpillar will fail to turn into a pupa. When the caterpillar fails to become the pupa, the caterpillar will remain in the final instars 
causing the caterpillar to decrease its feeding power so that the leaves will be less eaten by the caterpillar.

The percentage of residual leaves is one of the efficacy testing parameters that can demonstrate the success of bio-insecticide sample which can be seen based on the remaining leaves and not consumed by the caterpillar. Because with the fewer leaves that are consumed by caterpillars, the cysteine proteases contained in bio-insecticides successfully inhibit the caterpillar appetite and also damage the digestive system in the caterpillar. In addition, fewer leaves are eaten to reduce the level of losses and crop failure farmers [7].

The leaves to be tested are cut into $4 \times 4 \mathrm{~cm}$ to facilitate calculation. Then the leaves are divided into 4 quadrants and each quadrant is considered to represent $25 \%$ of the observed part. Here is the percentage of leaf residual data on peneliatian:

Table 1. Percentage of Residual Leaves

\begin{tabular}{|c|c|c|c|c|c|c|c|}
\hline Ratio 1:2 & $\mathbf{1}$ & $\mathbf{2}$ & $\mathbf{3}$ & $\mathbf{4}$ & $\mathbf{5}$ & $\mathbf{6}$ & $\mathbf{7}$ \\
\hline 10 minutes & 100 & 100 & 75 & 50 & 25 & 25 & 0 \\
\hline 20 minutes & 100 & 100 & 75 & 75 & 50 & 50 & 50 \\
\hline 30 minutes & 100 & 75 & 75 & 50 & 50 & 50 & 25 \\
\hline Ratio 2:1 & $\mathbf{1}$ & $\mathbf{2}$ & $\mathbf{3}$ & $\mathbf{4}$ & $\mathbf{5}$ & $\mathbf{6}$ & $\mathbf{7}$ \\
\hline 10 minutes & 100 & 100 & 100 & 100 & 100 & 50 & 50 \\
\hline 20 minutes & 100 & 100 & 75 & 75 & 0 & 25 & 0 \\
\hline 30 minutes & 100 & 100 & 100 & 75 & 25 & 25 & 0 \\
\hline Ethanol & $\mathbf{1}$ & $\mathbf{2}$ & $\mathbf{3}$ & $\mathbf{4}$ & $\mathbf{5}$ & $\mathbf{6}$ & $\mathbf{7}$ \\
\hline 10 minutes & 100 & 100 & 100 & 75 & 0 & 25 & 0 \\
\hline 20 minutes & 100 & 100 & 100 & 75 & 0 & 25 & 0 \\
\hline 30 minutes & 100 & 100 & 100 & 75 & 0 & 25 & 0 \\
\hline
\end{tabular}

Based on the above table it can be seen that in the sample there are still leaves left. This is due to the presence of bio-insecticide samples on the leaves that make the leaves no longer smell like fresh leaves so that the caterpillar becomes less interested to eat the leaves. The large percentage of leaves remaining is caused by papain that acts as an active agent in bio-insecticide which is a hydrolase enzyme that catalyzes the hydrolysis reaction of a substrate with the help of water molecules that have an effect on plant pest organisms [6].

With the action of repellent eating from the working system of papain enzymes that work as a stomach poison and contact, thus indicating the caterpillar that is in the instar phase 3 becomes inactive to eat and cause death caused by hunger.

\section{Conclusion}

Based on the result of this research, the best extraction was found on NADES solvent with 1: 2 ratio with 30 minutes extraction time. Obtained NADES solvent ratio of 1: 2 with extraction time for 30 minutes resulted in a protein concentration of $7.23 \mathrm{ppm}$ and a tyrosine concentration of $7.9 \mathrm{ppm}$. Bio-insecticide samples effectively kill grayak caterpillars with $100 \%$ mortality within 5-7 days.

\section{References}

Duan, L. 2016. Comprehensive Evaluation of
Deep Eutectic Solvents in Extraction of Bioactive Natural Products. Republic of China: China Pharmaceutical Uuniversity.

[2] Hartuti, S., \& Supardan, M. D. (2013). Optimasi Ekstraksi Gelombang Ultrasonik untuk Produksi Oleoresin Jahe Menggunakan Response Surface Methodology (RSM). Agritech, Vol.33, No.4, 415-423.

[3] Moehd. (2009). Bertanam pepaya.

[4] Morris, S. (2014). Effect of temperature and pH on enzyme activity. Retrieved 02 Juni, 2017, from Medicine, Science, \& Education Explored:

http://www.drupalbycity.com/effect-oftemperature-and-ph-on-enzyme-activity/

[5] Mukhriani. (2014). Ekstraksi, Pemisahan Senyawa, dan Identifikasi Senyawa Aktif. Jurnal Kesehatan Volume VII No.2, 361-367.

[6] Ningrum, 2014. Rendaman daun pepaya sebagai pestisida nabati pengendali hama ulat grayak.

[7] Nur, D. F. (2017). Produksi Biopestisida Berbasis Enzim Sisteina Protease dari Getah Pepaya untuk Ulat Grayak pada Tanaman Cabai Merah. Depok: Universitas Indonesia.

[8] Prijono, D. 2007 Modul Praktikum Toksikologi Insektisida Pengujian

Toksisitas Insektisida.Departemen Proteksi Tanaman. IPB. Bogor.

[9] Williams, A. R. (1983). Ultrasound : Biological Effects and Potential Hazards. -: Academic Press.

[10] Yang, L. 2011. Ultrasound-assisted extraction of the three terpenoid indole alkaloids vindoline catharanthine and vinblastine from Catharanthus roseus using ionic liquid aqueous solutions. China: Northeast Forestry University.

[11] Zuchner, D. T. (2017). Working with proteins: protein stability and storage-a brief guide. Retrieved 01 Juni, 2017, from http://research.unileipzig.de/uspdu/docs/Protein\%20guide_Stora ge_Working.pdf 